\title{
COMPARATIVE ANALYSIS OF ABNORMAL RETURNS OF STOCKS AND UBS GOLD BEFORE AND AFTER THE ANNOUNCEMENT OF THE COVID-19 PANDEMIC
}

\author{
Qamaral Shabrina Agfah*1, Muhammad Azhari² \\ Universitas Telkom, Indonesia*12 \\ qamaralshabrina@student.telkomuniversity.ac.id ${ }^{* 1}$, muhazhari@gmail.com² $^{2}$
}

\begin{abstract}
Currently, the economy and capital market in Indonesia are experiencing a decline in performance due to the COVID-19 pandemic. This research was conducted to analyze whether there is a difference in the return of shares in the transportation subsector and UBS gold to the current COVID-19 pandemic, by looking at changes in prices 7 days before and 7 days after the announcement of the COVID- 19 Pandemic announced by President Joko Widodo on March 2, 2020. The phenomena contained in this study were carried out by the event study with the abnormal return technique. This study using data in the form of secondary data and data taken by time series. The sample used in this research is data on the closing price of 7 days of 1-gram UBS pure gold before and after the COVID-19 pandemic and 23 shares of the transportation sub-sector listed on the Indonesia Stock Exchange. Data analysis used abnormal return, normality test, and paired sample t-test using IBM SPSS. This study found that there was no difference in the abnormal return of shares in the transportation sub-sector and UBS Gold at the time of the announcement of the COVID-19 pandemic in Indonesia by Joko Widodo.
\end{abstract}

Keywords: Abnormal Return; COVID-19 Pandemic; Event Study; Shares in the Transportation Subsector; UBS Gold

\section{INTRODUCTION}

Investment is a delay in the use of funds or money for a certain time to obtain future benefits (Tandelilin, 2010). Investments are very popular with people today, especially regarding capital market investment. The capital market also has various choices, including stocks and gold. According to Brigham \& Houston (2010), there are internal and external factors that affect stock price fluctuations. Internal factors that affect share prices include change of directors, management, or organizational structure, financial statement announcements, investment announcements. The external factors that can influence investors in the capital market are exchange rates, inflation, and interest rates. COVID-19 or the coronavirus is a virus that is in the body of animals or humans. COVID19 is a contagious and newly discovered disease. At first, this virus originated from an outbreak in Wuhan, China, in December 2019, but until now it has become a worldwide pandemic (WHO, 2020)

Currently, the economy and capital market in Indonesia are experiencing a decline in macro performance due to the COVID-19 Pandemic. This incident also had a very influential impact on stock prices as well as gold. The Composite Stock Price Index (IHSG) has decreased to the closing price of 5,361.25 which is considered weak in the past month (Istianur, 2020). Meanwhile, the price of gold bullion has increased by Rp. 4,000 to the level of Rp. 810,000 per gram and the repurchase price or buyback also increased by Rp. 4,000 to Rp. 732,000 per gram (Fadhlurrahman \& Sutianto, 2020).

The main difference in the characteristics of shares and gold is the shape of the shares in the form of ownership certificates, but gold has a form that can be seen and touched (Ma'ruf, 2019). With their respective characteristics, they both depend on the economy of a country, so that if an event occurs, it can be used as an event study for a study. 
The event in this research is the announcement of the COVID-19 Pandemic. In this study, abnormal returns were used to analyze whether there were differences in the returns stock of the transportation sub-sector and UBS gold on the announcement of the current COVID-19 Pandemic, by looking at price changes 7 days before and 7 days after the announcement of the COVID-19 Pandemic announced by President Joko Widodo.

The capital market is an abstract market where goods traded are in the form of several long-term bond funds that can be disbursed within a minimum period of one year (Widoatmodjo, 2012). Whereas the concept of an efficient market, namely the market concept that is available to information where the price of the security in the information is available (Tandelilin, 2010). According to Fama, 1970 in Hartono (2013), the efficiency market has 3 (three) forms, namely: weak-form market efficiency, semi-strong form market efficiency (strong form). The efficiency of information can affect stock prices and gold.

Stock is an instrument in the capital market that has a high rate of return so that it is in demand by investors. The form of shares is a paper that has a nominal value, the name of the company, then the rights and obligations that have been explained to the holders (Fahmi, 2012). Gold is a type of yellow precious metal that is most in demand by the Indonesian market. Gold is often used as jewelry such as rings, bracelets, or necklaces (KBI, 2019)

In investing, of course, the goal is to returns stocks that are by following per under those expected by investors by achieving large profits. Event study or commonly referred to as event study is a method used to observe market reactions to an event (Hartono, 2013). The existence of an event can determine the return using techniques abnormal return. Abnormal return is a result of before and after the event in the form of the difference between the expected profit and the actual profit.

Research conducted in Liu et al. (2020) regarding The COVID-19 Outbreak and Affected Countries Stock Markets Response. This research shows that the stock market in Asia, especially Hong Kong, Malaysia, Japan, Thailand, and China shows that the stock market has a negative influence that will not last long, but for countries outside Asia there is no visible decline. Then, research conducted by Ratnaningsih \& Widanaputra (2019) with the title The Reaction of Indonesian Capital Market to Political Event the Announcement of Indonesia Presidential Election 2019 Results (Event Study on KOMPAS 100). From this research, it is found that there is an abnormal return significant around the window of the event, and on average it has a positive impact that is welcomed by the market. Research conducted by Nawangsari \& Iswajuni (2019) on The effects of auditor switching towards abnormal return in manufacturing companies. It can be obtained that the research results show that simultaneous auditor changes affect abnormal returns. Some auditors switch, only the CU switch affects the abnormal return.

This study aims to determine whether there are differences in abnormal returns of transportation sub-sector Stockland gold bullion from UBS before and after the announcement of the COVID-19 pandemic by the president of the Republic of Indonesia, Joko Widodo. In this study, to be able to obtain a study of the announcement of the COVID-19 Pandemic, we used the method event study with a technique abnormal return with a 15-day event window, 7 days before the announcement, when the announcement was made, and 7 days after the announcement. Also, because we are using a market model, we set 100 days to be used as the estimation period to get the beta results. If there is a difference in abnormal returns, the market receives negative information so that it experiences a loss in return on its investment, but if there is no difference in abnormal returns, the market accepts the market positively so returns that the resulting movie is stable or even experiences profits. 


\section{METHODS}

This research uses the method event study or event study with the technique abnormal return market model. This study uses a total population of shares in the transportation sub-sector in the Indonesia Stock Exchange as many as 43 companies and UBS gold in the form of jewelry and bars. The sampling technique used in this study was non-probability sampling with purposive sampling type. The criteria used are: UBS gold in the form of gold bars with a size of 1 gram, transportation sub-sector stock companies that are still listed on the IDX, remain active in buying and selling transactions, have historical data complete, no rights issue, and do not have deferred shares.

The data used in this study are secondary, this data is data on the closing price of each issuer, the composite stock price index, and UBS gold obtained from www.idx.co.id, www.bi.go.id, and www.finance.yahoo.com.

In this study, data analysis techniques are used to test hypotheses in the form of event studies, abnormal returns, and classical assumption tests. In this study using the event date on 2 March 2020 as day 0, an estimation period of 100 days with details before the 7th day of the event, and an event window of 15 days, 7 days before, and 7 days after the COVID-19 Pandemic. $(h-7$ to $h+7)$.

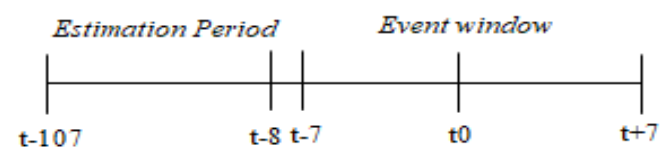

Figure 1. Event Window

Source: Processed Data (2021)

In conducting data analysis, the first thing to do is to analyze descriptive statistics of all the samples used. Then test the normality of the data for the two objects using the Kolmogorov Smirnov. If the AAR data is normal, then in hypothesis testing or the average difference test uses the Paired Sample T-Test, but if it is not normal then use the Nonparametric Wilcoxon Signed Rank Test to fulfill the assumptions. Whereas in testing the UBS gold average difference using the Independent Samples Test.

\section{RESULTS AND DISCUSSION}

The use of data in this study is in the form of a closed price sample for 7 days before the event, at the time of the event, 7 days after the event, and 100 days before the event, the details of the event date are as follows: (1) Announcement of the COVID19 Pandemic in Indonesia on March 2, 2020; (2) Window of Events on February 20, 2020, to March 11, 2020; (3) Estimation Period on September 26, 2019, to February 19, 2020.

The sample in this study is UBS gold in the form of bars worth 1 gram and 23 shares of transportation sub-sector companies listed on the Indonesia Stock Exchange, active In share buying and selling transactions, there are no rights issues, have complete historical data, and do not have deferred shares. Following are the details of the stocks sampled in the study: 
Table 1. List of Company Shares in Transportation Subsector

\begin{tabular}{l} 
Emiten \\
\hline Adi Sarana Armada Tbk. \\
Majapahit Inti Corpora Tbk \\
Blue Bird Tbk. \\
Batavia Prosperindo Trans Tbk. \\
PT. Buana Listya Tam Tbk. \\
Dewata Freightinternational Tbk. \\
Garuda Indonesia (Persero) Tbk. \\
Jaya Trishindo Tbk. \\
Humpuss Intermoda Transportasi \\
Jasa Armada Indonesia Tbk. \\
Mitra Bahtera Segara Sejati Tbk. \\
PT. Pelita Samudera Shipping Tbk. \\
Rig Tenders Indonesia Tbk. \\
Steady Safe Tbk. \\
Sillo Maritime Perdana Tbk. \\
Samudera Indonesia Tbk. \\
Sochi Lines Tbk. \\
PT. Pelayaran Tamarin Samudra Tbk. \\
Transco Pacific Tbk \\
Pelayaran Tempuran Emas Tbk. \\
PT. Guna Timur Raya \\
Weha Tranportasi Indonesia Tbk. \\
Wintermar Offhore Marine Tbk.
\end{tabular}

Source: Processed Data (2021)

Calculation results of Average Abnormal Return of Shares in Transportation and UBS Gold: 
Table 2. Average Abnormal Return

\begin{tabular}{ccc}
\hline Index & $\begin{array}{c}\text { AAR } \\
\text { (Before) }\end{array}$ & AAR (After) \\
\hline BTPR & 0.003 & 0.008 \\
GIAA & -0.029 & 0.004 \\
IPCM & 0.002 & -0.007 \\
ASSA & -0.005 & -0.004 \\
MBSS & -0.010 & -0.011 \\
DEAL & 0.090 & 0.019 \\
AKSI & -0.021 & -0.007 \\
HITS & 0.012 & 0.003 \\
BIRD & 0.000 & -0.008 \\
HELI & 0.008 & -0.010 \\
SMDR & -0.011 & -0.003 \\
TCPI & 0.000 & -0.017 \\
BULL & -0.002 & -0.005 \\
RIGS & -0.010 & 0.001 \\
SAFE & 0.012 & 0.008 \\
SHIP & 0.003 & 0.002 \\
SOCI & -0.024 & 0.008 \\
TAMU & -0.054 & 0.043 \\
TMAS & -0.006 & 0.004 \\
TRUK & 0.003 & -0.003 \\
WEHA & -0.023 & -0.006 \\
WINS & -0.009 & -0.011 \\
PSSI & 0.002 & -0.002 \\
Emas & 0.014 & 0.004 \\
UBS & & \\
\hline & &
\end{tabular}

Source: Processed Data (2021)

The results of the data normality test of the Transportation Sub Sector used are the results of 3 . Tests of Kolmogorov Smirnov.

Table 3. Normality Test Results for Transportation Sub Sector Stock

\begin{tabular}{llll}
\hline & \multicolumn{3}{c}{ Kolmogorov-Smirnov } \\
& Statistic & \multicolumn{1}{c}{ df } & Sig. \\
\hline AARSBLM & 0.229 & 23 & 0.003 \\
AARSSDH & 0.169 & 23 & 0.088 \\
\hline
\end{tabular}

Source: Processed Data (2021)

From table 3 overall results, it can be concluded that the Average Abnormal Return before the announcement got a result of 0.003 which means that the data is not normally distributed, while the Average Abnormal Return after the announcement got a result of 0.088 , which means the data is normally distributed. With different data results on the 
Average Abnormal Return before and after, hypothesis testing can be done using the nonparametric Wilcoxon signed-rank test to meet the assumptions.

Table 4. UBS Gold Data Normality Test Results

\begin{tabular}{cccc}
\hline & \multicolumn{3}{c}{ Kolmogorov-Smirnov } \\
Statistic & df & Sig. \\
\hline AR & 0.166 & 15 & 0.200 \\
\hline \multicolumn{3}{c}{ Source: Processed Data $(2021)$}
\end{tabular}

From table 4 , there is a significant result of 0.200 , which means $>0.05$ so that the data is normally distributed. With the results of the data that are normally distributed, it can be done by testing the hypothesis by using different test independent samples to meet the assumptions.

Table 5. Wilcoxon Signed Ranks

\begin{tabular}{lr}
\hline \multicolumn{2}{c}{ AARSSDH - AARSBLM } \\
\hline$Z$ & -0.274 \\
Asymp. Sig. & 0.784 \\
(2-tailed) & \\
\hline \multicolumn{2}{c}{ Source: Processed Data (2021) }
\end{tabular}

In table 5, it shows that the probability value obtained from the Average Abnormal Return Before and After is greater than the predetermined significance level, namely 0.05 , the value is $0.784>0.05$, thus proving the assumption. accepted, which means that there is no difference in the abnormal return of shares in the transportation subsector between before and after the announcement of the COVID-19 Pandemic in Indonesia.

Table 6. Independent Samples Test Results

\begin{tabular}{|c|c|c|c|}
\hline \multirow{3}{*}{ AR } & \multicolumn{3}{|c|}{ T-Test for Equality of Means } \\
\hline & & df & $\begin{array}{l}\text { Sig. (2 } \\
\text { tailed) }\end{array}$ \\
\hline & $\begin{array}{l}\text { Equal variances } \\
\text { assumed }\end{array}$ & 12 & 0.309 \\
\hline
\end{tabular}

Source: Processed Data (2021)

In table 6 , it can be seen that the sig (2-tailed) value or probability on the equal variances assumed is greater than the predetermined level of significance, namely 0.05 . The value of sig (2-tailed) is $0.309>0.05$, so it proves the accepted assumption, which means that there is no difference in the

\section{CONCLUSION}

From the results of different tests on the abnormal return of shares in the transportation sub-sector and UBS Gold, it shows that there is no difference in abnormal returns 7 before and 7 days after the announcement of the COVID-19 pandemic in Indonesia. This happens because the information that comes from the event is not sufficient to make a stock price movement abnormal, so there is no significant change in return. Also Besides, gold objects are primary assets where the effect of changes in return does not depend on the activities of humans, companies, or certain entities so that there is no difference due to the announcement of the COVID-19 pandemic and also to 
at the time of the announcement of the COVID-19 pandemic that occurred on March 2. 2020 and the social restrictions (PSBB) have not been held, so returns stock in the transportation sub-sector do not affect on the announcement of the large-scale COVID19 pandemic. abnormal return of UBS Gold between before and after the announcement of the COVID-19 Pandemic in Indonesia.

\section{REFERENCES}

Brigham, F, E., \& Houston. (2010). Dasar-Dasar Manajemen Keuangan. Edisi 11. Jakarta: Selemba Empat.

Fadhlurrahman, Ferry \& Sutianto, Feby Dwi. (2020). Harga Emas. Retreived March 2, 2020, Website: https://kumparan.com/kumparanbisnis/awal-maret-harga-emasnaik-rp-4-000-per-gram-1swgS37NsNq

Fahmi, I. (2012). Analisis Kinerja Keuangan. Alfabeta.

Fama, E. F. (1970). Efficient Capital Markets: A Review of Theory and Empirical Work. The Journal of Finance. https://doi.org/10.2307/2325486

Hartono, J. (2013). Metodologi Penelitian Bisnis Salah Kaprah dan Pengalamanpengalaman (Kelima). Yogyakarta: BPFE.

Istianur, I. (2020). HEADLINE: Bursa Saham dan Rupiah Terempas Virus Corona, Apa Skenario Indonesia untuk Bangkit?. website: https://www.liputan6.com/bisnis/read/4205445/headline- bursa-saham-danrupiah-terempas-virus-corona-apa-skenario-indonesia-untuk- bangkit

$\mathrm{KBI}$ (2019). Emas. Online.

Liu, H., Manzoor, A., Wang, C., Zhang, L., \& Manzoor, Z. (2020). The COVID-19 Outbreak and Affected Countries Stock Markets Response. Table 1, 1-19.

Ma'ruf. (2019). Perbedaan Saham dan Obligasi Secara Umum. Retrieved September 2, 2020, website: https://www.akuntansilengkap.com/bisnis/perbedaan-saham-danobligasi-secara-umum-dan-contohnya/

Nawangsari, F. Y., \& Iswajuni, I. (2019). The effects of auditor switching towards abnormal return in manufacturing company. Asian Journal of Accounting Research. https://doi.org/10.1108/ajar-05-2019-0040

Ratnaningsih, N. M. D., \& Widanaputra, A. A. G. P. (2019). The reaction of Indonesian capital market to political event the announcement of Indonesia presidential election 2019 results. International Research Journal of Management, IT and Social Sciences, 6(6), 87-94. https://doi.org/10.21744/irjmis.v6n6.765

Tandelilin, E. (2010). Portofolio dan investasi. Yogyakarta: Kanisius.

WHO. (2020). COVID-19. Pertanyaan dan jawaban terkait Coronavirus, Retreived 3 September 2020, website: https://www.who.int/indonesia/news/novelcoronavirus/qa/qa-for-public.

Widoatmodjo, Sawidji. (2012). Cara Sehat Investasi di Pasar Modal. Edisi Revisi. Jakarta: PT. Jurnalindo Aksara Grafika. 